\title{
REVIEW \\ Studies on Speciation in Genus Lycoris Using Interspecific Hybrids and Selfed Plants Produced through Embryo Rescue
}

\author{
Isao TARUMOTO ${ }^{1,2 *}$, Biao MA ${ }^{1,3}$ and Takeshi OGAWA ${ }^{1}$ \\ ${ }^{1}$ Laboratory of Genetics and Plant Breeding, Graduate School of Agriculture and Biological Sciences, \\ Osaka Prefecture University (Sakai, Osaka 599-8231, Japan)
}

\begin{abstract}
This study was carried out to overcome the problems that impede genetic improvement of Lycoris. An improved ovule culture method was developed to rescue the abortive embryo in order to overcome the poor fertility in hybridization of Lycoris. Using this method, a large number of selfed and crossed plants in several species were produced, and the interspecific hybrids which used $L$. incarnata (sterile) as a cross parent were obtained for the first time. Cytological studies of the $\mathrm{S}_{1}$ plants indicated that polyploidization and aneuploid reduction caused by self-pollination should be among the major factors affecting karyotype evolution in some Lycoris species. Allozyme segregations in polymorphic loci of APT, GOT and EST were observed in $\mathrm{S}_{1}$ of five diploid species, suggesting that each of the species is originally heterozygous. The investigation using genomic in situ hybridization (GISH) was done to clarify the chromosome constitution in Lycoris. The distinction between $\mathrm{M}+\mathrm{T}$ and A type chromosomes at the DNA sequence level demonstrated that genome differentiation has occurred in the genus Lycoris.
\end{abstract}

Discipline: Plant breeding / Horticulture

Additional key words: allozyme, Amaryllidaceae, genomic in situ hybridization (GISH), karyotype, ovule culture, polyploid

\section{Introduction}

The genus Lycoris, a member of the family Amaryllidaceae, contains about 20 species. Most of the species are commonly cultivated in China, Japan, and the United States as bulbous plants ${ }^{2,7}$. Recently, the demand for cut flowers of Lycoris has increased with diversification of flower consumption, so breeding of varieties with new flower forms and/or colors has become desirable for Lycoris $^{15}$.

At present, the hybridization between Lycoris species is most promising for improving and diversifying certain traits. However, the breeding efficiency in interspecific hybridization is low mainly due to the difficulty of obtaining $\mathrm{F}_{1}$ plants caused by incongruity ${ }^{4}$, inefficient embryo rescue technique ${ }^{39}$ and so on. Moreover, little knowledge of the genetic background of Lycoris species as well as the inheritance of characters is available. For elucidating the genetic relationship among species and karyotype evolution, cytological studies on selfed plants and interspecific hybrids have been made by some authors, such as Kihara \& Koyama $^{16}$, Koyama ${ }^{17-19}$, Takemura $^{35-37}$, and Shii et al. ${ }^{34}$. However, more information is needed to clarify the genetic background of Lycoris species. Therefore, the authors studied the embryo rescue $e^{25,27,28}$ and speciation ${ }^{25,26,29,30,33}$ in Lycoris. This report deals with ovule culture for obtaining more progeny plants via self-pollination and interspecific hybrids, and with cytological, allozyme and genomic in situ hybridization (GISH) studies for revealing specific relationships in Lycoris.

\footnotetext{
Present address:

2 (Tsukuba, Ibaraki 305-0051, Japan)

${ }^{3}$ Gene Research Center, University of Tsukuba (Tsukuba, Ibaraki 305-8572, Japan)

*Corresponding author: fax +81-29-855-1082; e-mail i_taru2006@ybb.ne.jp

Received 14 October 2005; accepted 16 January 2006.
} 


\section{Production of interspecific hybrids and selfed plants in Lycoris}

Interspecific and intergeneric crosses have been made to introduce new genetic variation into cultivated plants. For ornamental bulbs such as Lilium and Narcissus, interspecific hybridization has been frequently used to improve flower shape and color and to extend the flower period ${ }^{24,39}$. However, in general, the incongruity that occurs before and after pollination often becomes a barrier for producing interspecific hybrids.

In Lycoris, incongruity and sterility prevent successful hybridization. In many cases, although pollens of Lycoris species are fertile and the fertilization is normally done $^{8-10,34}$, the embryos after pollination are generally weak and prone to abort ${ }^{8-10,18}$. Several methods have been developed to solve the problems. The 'Mizusashi method ${ }^{38}$ of keeping the scapes in a flask of water after pollination was usually employed to mature seeds ${ }^{16-18,34-37}$, and the immature seeds developed by the Mizusashi method were then cultured in vitro ${ }^{10,15}$. However, the seed formation rates through them were still low and the hybridity of $F_{1}$ plants was not confirmed. Moreover, in many 'sterile' Lycoris species caused by irregular meiotic division and nonhomologous pairing ${ }^{8,9,32}$, interspecific hybrids have not been produced. Thus, the authors developed the efficient embryo rescue method ${ }^{27}$ and produced interspecific hybrids and selfed plants ${ }^{25,26,28}$ in various Lycoris species including the sterile species L. incarnata.

\section{An ovule culture for improving the efficiency of seedling formation}

Scapes of $L$. sanguinea, a 'fertile' species $(2 \mathrm{n}=$ 22A) as defined only by its normal meiotic division ${ }^{32}$, were cut just before anthesis and kept in flasks filled with tap water according to the Mizusashi method ${ }^{18}$. The ovules were isolated 20 days after self-pollination as in Ma et al. ${ }^{27}$, and were imbedded in several culture mediums. The modified components such as sucrose, $\mathrm{pH}$ and casein hydrolysate $(\mathrm{CH})$, resulted in a MS medium containing 3\% sucrose at $\mathrm{pH} 5.8$ which was satisfactory for ovule culture. A modified MS medium (mMS2) containing macro-salts, adopted from Monnier's medium ${ }^{31}$ containing $3 \%$ sucrose at $\mathrm{pH} 5.8$, induced higher germination

Table 1. Relative efficiency of casein hydrolysate $(\mathrm{CH})$ supplement on obtaining seedlings from ovules obtained 20 days after self-pollination in L. sanguinea (Sucrose: $3 \%$, pH: 5.8 )

\begin{tabular}{|c|c|c|c|}
\hline Medium & No. of ovules inoculated & $\%$ of ovules germinated ${ }^{a)}$ & $\%$ of seedlings obtained ${ }^{b}$ \\
\hline $1 / 2 \mathrm{MS}$ & 18 & 44.4 & 20.2 \\
\hline $1 / 2 \mathrm{MS}+\mathrm{CH}^{\mathrm{c})}$ & 19 & 63.2 & 26.3 \\
\hline $\operatorname{mMS} 2^{d)}$ & 12 & 50.0 & 25.0 \\
\hline $\mathrm{mMS} 2+\mathrm{CH}$ & 17 & 88.2 & 70.6 \\
\hline
\end{tabular}

a): $\%$ of ovules germinated $=$ No. of ovules germinated $/$ No. of ovules inoculated.

b): $\%$ of seedlings obtained $=$ No. of seedlings obtained $/$ No. of ovules inoculated.

c): $500 \mathrm{mg} / \mathrm{L} \mathrm{CH}$ was added to the basal media.

d): $\mathrm{mMS} 2$ medium with reduced ammonium concentration by half $\left(825 \mathrm{mg} / \mathrm{L} \mathrm{NH}_{4} \mathrm{NO}_{3}\right)$, increased potassium level (adding $350 \mathrm{mg} / \mathrm{L} \mathrm{KCl}$ ) and doubled calcium chloride concentration $\left(880 \mathrm{mg} / \mathrm{L} \mathrm{CaCl} \cdot 2 \mathrm{H}_{2} \mathrm{O}\right)$.

Table 2. Relative efficiency of ovule culture in Lycoris using mMS2 + CH medium

\begin{tabular}{|c|c|c|c|}
\hline Source of ovules & No. of ovules cultured ${ }^{\text {a) }}$ & $\%$ of ovules germinated ${ }^{\text {b) }}$ & $\%$ of seedlings obtained ${ }^{c)}$ \\
\hline L. albiflora $\times$ L. sanguinea & 26 & 23.1 & 15.4 \\
\hline L. radiata $\times$ L. sanguinea & 37 & 54.1 & 43.2 \\
\hline L. albiflora ${ }^{\mathrm{d})} \quad$ selfed & 10 & 30.0 & 20.0 \\
\hline L. radiata $^{\text {d) }} \quad$ selfed & 26 & 15.4 & 11.5 \\
\hline L. sanguinea $^{\text {e) }}$ selfed & 18 & 88.9 & 83.3 \\
\hline
\end{tabular}

a): The ovules were isolated 30 days after self- or cross-pollination.

b): $\%$ of ovules germinated $=$ No. of ovules germinated $/$ No. of ovules inoculated.

c): $\%$ of seedlings obtained $=$ No. of seedlings obtained $/$ No. of ovules inoculated.

d): L. albiflora and L. radiata are "sterile" species with irregular meiotic division.

e): L. sanguinea is a "fertile" species with normal meiotic division. 
and seedling formation rates. The addition of $500 \mathrm{mg} \cdot \mathrm{L}^{-1}$ $\mathrm{CH}$ to mMS2 medium (mMS2 $+\mathrm{CH}$ ) promoted the germination and seedling formation rates (Table 1$)^{27}$. The seedling formation rates in L. sanguinea were satisfactorily high compared with the current record of 0.12 selfed plants per floret ${ }^{35}$. These results indicate that higher levels of potassium and calcium and lower level of ammonium are more suitable for ovule culture, and $\mathrm{CH}$ would contribute to the promotion of in vitro growth of immature embryos as well as to the inhibition of abnormal embryo development as reported by Ziebur et al. ${ }^{43}$.

L. sanguinea (diploid, $2 \mathrm{n}=22$ ) is a "fertile" species defined by the normal meiotic division ${ }^{32}$, whereas L. albiflora (diploid, $2 \mathrm{n}=17$ ) and L. radiata (triploid, $2 \mathrm{n}=33$ ) are "sterile" ones defined by the irregular meiotic division $^{8,9}$ and had no record of selfed plants ${ }^{9,10}$. It has been difficult to obtain selfed progenies as well as hybrid plants in "sterile" species even through the Mizusashi method $^{15,18}$ because of nutrient shortage to developing embryos $^{15}$ and/or chromosomal unbalance in recombination $^{8,9}$. The $\mathrm{mMS} 2+\mathrm{CH}$ medium proved satisfactory for producing them in "sterile" Lycoris species (Table 2$)^{27}$. The seedling formation rates of selfed $L$. albiflora and L. radiata were $20.0 \%$ and $11.5 \%$, and the rates of hybrids were $15.4 \%$ in L. albiflora $\times L$. sanguinea and $43.2 \%$ in L. radiata $\times L$. sanguinea. The hybridity was proved by their chromosome numbers $(2 \mathrm{n}$ $=20-21$ in L. albiflora $\times$ L. sanguinea and $2 \mathrm{n}=24-28$ in L. radiata $\times$ L. sanguinea $)^{26}$. These satisfactory results are considered to be attributed to the adequate nutrient supply to the immature embryo from mMS2 $+\mathrm{CH}$ medium.

\section{Interspecific hybrids and selfed plants via ovule culture}

A wide range of interspecific crosses by using "fertile" and "sterile" species was carried out using our ovule culture method, in order to prove the applicability for producing interspecific hybrids in Lycoris. The $\mathrm{S}_{1}$ plants were obtained in 5 fertile species and 2 sterile species, and $F_{1}$ plants were obtained in 17 out of 21 combinations carried out (Table 3$)^{25}$. Even through ovule culture, the combinations of sterile $\times$ sterile did not produce hybrid plants (Table 3$)^{25}$. The hybridity of $F_{1}$ plants was confirmed by cytological studies ${ }^{25,26}$, and in the case that both parents have identical karyotype, isozyme analysis was done to confirm the hybridity ${ }^{25}$. In the results, all the $\mathrm{F}_{1}$ plants produced were proved to be true hybrids, and all the hybrids of sterile $\times$ fertile were aneuploids, for example $2 \mathrm{n}=23$ to 31 in L. radiata $\times$ L. sanguinea and $2 \mathrm{n}=23$ to 28 in L. radiata $\times$ L. sprengeri, providing new breeding sources like the promising aneuploid cultivars bred in
Nerine $^{11}$ and Narcissus ${ }^{4,40}$.

\section{Interspecific hybrids between Lycoris incarnata and other species through embryo culture}

Several traits of L. incarnata $(2 \mathrm{n}=3 \chi=30,3 \mathrm{M}+$ $\left.5 \mathrm{~T}+20 \mathrm{~A}+1 \mathrm{M}^{\prime}+1 \mathrm{~m}\right)^{7,23}$ such as funnel flower form, light rose color, and strong scapes are desirable for developing varieties with these characters. However, it has been difficult to produce interspecific hybrids using $L$. incarnata because of its sterility with irregular meiotic division. We made interspecific crosses between sterile species (L. incarnata) and four fertile species (L. sanguinea, L. sprengeri and $L$. radiata var. pumila $=2 \chi=$ $22 \mathrm{~A} ; L$. aurea $=2 \chi=8 \mathrm{M}+6 \mathrm{~T})$. The embryos, excised from ovules grown 20-30 days in the Mizusashi method after pollination, were cultured on the mMS $+\mathrm{CH}$ medium $^{27}$. Interspecific crosses using L. incarnata as a female parent yielded 26 hybrid plants, whereas that of $L$. sanguinea $\times$ L. incarnata produced none (Table 4$)^{28}$. Cytological studies revealed that all hybrids were tetraploid (Table 5$)^{28}$, which would have originated from the fertilization of an unreduced $2 \mathrm{n}$ - egg of the female parent (L. incarnata) and a normal haploid gamete of the male parent. The hybridity was also confirmed by isozyme analysis in 26 hybrid plants (Fig. 1) ${ }^{28}$. This is the first record in producing true interspecific hybrid plants using the sterile species, L. incarnata.

\section{Speciation in genus Lycoris}

Genetic relationship is useful for evolutionary studies and selecting of suitable parents in a breeding

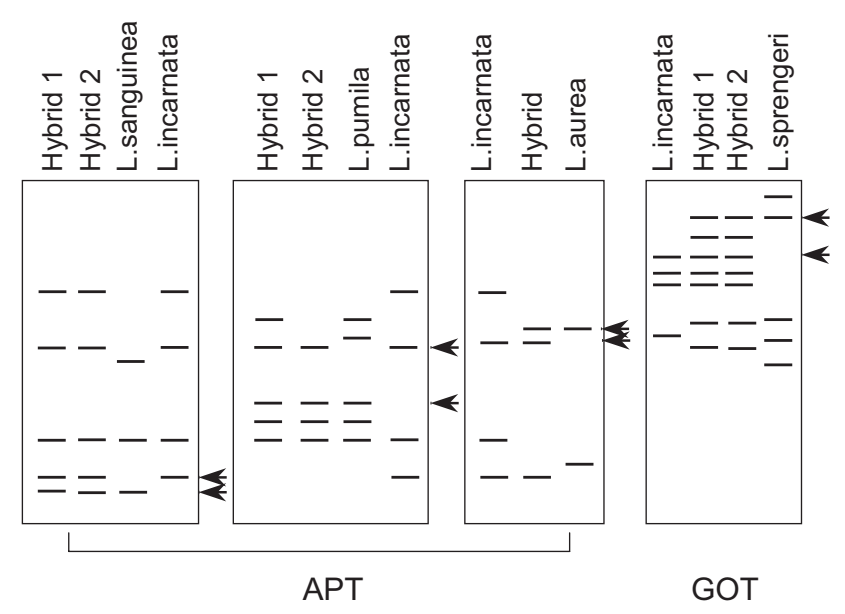

Fig. 1. Zymograms for APT and GOT in interspecific hybrids and their parents 
Table 3. Interspecific hybrids and selfed plants produced through ovule culture in Lycoris

\begin{tabular}{|c|c|c|c|c|c|c|c|}
\hline \multicolumn{2}{|c|}{ Cross combination } & \multirow{2}{*}{$\begin{array}{l}\text { No. of florets } \\
\text { pollinated }\end{array}$} & \multirow{2}{*}{$\begin{array}{l}\% \text { of } \\
\text { fruit set }\end{array}$} & \multirow{2}{*}{$\begin{array}{l}\text { No. of ovules } \\
\text { cultured }^{\text {a) }}\end{array}$} & \multirow[t]{2}{*}{ Medium } & \multirow{2}{*}{$\begin{array}{c}\% \text { of } \\
\text { germination }\end{array}$} & \multirow{2}{*}{$\begin{array}{c}\% \text { of seedling } \\
\text { formation }\end{array}$} \\
\hline ( 우) & $\left(\sigma^{\lambda}\right)$ & & & & & & \\
\hline \multirow[t]{4}{*}{ L. sanguinea } & self & 143 & 66.4 & 124 & $1 / 2 \mathrm{MS}$ & 69.4 & 56.5 \\
\hline & & & & 18 & $\mathrm{mMS} 2+\mathrm{CH}$ & 88.9 & 83.3 \\
\hline & $\times$ L. pumila $^{\mathrm{b})}$ & 18 & 50.0 & 16 & $\mathrm{mMS} 2+\mathrm{CH}$ & 50.0 & 50.0 \\
\hline & $\times$ L. squamigera & 101 & 56.4 & 59 & $1 / 2 \mathrm{MS}$ & 16.9 & 15.3 \\
\hline \multirow[t]{4}{*}{ L. sprengeri } & self & 52 & 71.2 & 39 & $1 / 2 \mathrm{MS}$ & 48.7 & 43.6 \\
\hline & & & & 65 & $\mathrm{mMS} 2+\mathrm{CH}$ & 53.8 & 49.2 \\
\hline & $\times$ L. sanguinea & 12 & 91.7 & 34 & $1 / 2 \mathrm{MS}$ & 38.2 & 38.2 \\
\hline & $\times$ L. albiflora & 9 & 77.8 & 23 & $1 / 2 \mathrm{MS}$ & 65.2 & 56.5 \\
\hline \multirow[t]{5}{*}{ L. aurea } & self & 30 & 83.3 & 49 & $1 / 2 \mathrm{MS}$ & 85.7 & 65.3 \\
\hline & & & & 46 & $\mathrm{mMS} 2+\mathrm{CH}$ & 95.7 & 93.5 \\
\hline & $\times$ L. sanguinea & 7 & 85.7 & 12 & $1 / 2 \mathrm{MS}$ & 83.3 & 66.7 \\
\hline & $\times$ L. sprengeri & 10 & 90.0 & 20 & $1 / 2 \mathrm{MS}$ & 60.0 & 60.0 \\
\hline & $\times$ L. albiflora & 8 & 75.0 & 11 & $1 / 2 \mathrm{MS}$ & 90.9 & 50.0 \\
\hline \multirow[t]{9}{*}{ L. albiflora } & self & 56 & 62.5 & 9 & $1 / 2 \mathrm{MS}$ & 11.1 & 11.1 \\
\hline & & & & 10 & $\mathrm{mMS} 2+\mathrm{CH}$ & 30.0 & 20.0 \\
\hline & $\times$ L. sanguinea & 45 & 44.4 & 17 & $1 / 2 \mathrm{MS}$ & 5.9 & 5.9 \\
\hline & & & & 26 & $\mathrm{mMS} 2+\mathrm{CH}$ & 23.1 & 15.4 \\
\hline & $\times$ L. sprengeri & 35 & 57.1 & 25 & $1 / 2 \mathrm{MS}$ & 40.0 & 28.0 \\
\hline & $\times$ L. aurea & 14 & 42.9 & 6 & $1 / 2 \mathrm{MS}$ & 50.0 & 33.3 \\
\hline & $\times$ L. squamigera & 18 & 27.8 & 0 & - & - & - \\
\hline & $\times L$. radiata & 44 & 40.9 & 12 & $1 / 2 \mathrm{MS}$ & 0 & - \\
\hline & & & & 8 & $\mathrm{mMS} 2+\mathrm{CH}$ & 0 & - \\
\hline \multirow[t]{10}{*}{ L.radiata } & self & 35 & 68.6 & 39 & $1 / 2 \mathrm{MS}$ & 12.8 & 5.1 \\
\hline & & & & 26 & $\mathrm{mMS} 2+\mathrm{CH}$ & 15.4 & 11.5 \\
\hline & $\times$ L. sanguinea & 96 & 79.2 & 102 & $1 / 2 \mathrm{MS}$ & 41.2 & 28.4 \\
\hline & & & & 37 & $\mathrm{mMS} 2+\mathrm{CH}$ & 54.1 & 43.2 \\
\hline & $\times$ L. sprengeri & 41 & 68.3 & 46 & 1/2 MS & 28.3 & 21.7 \\
\hline & $\times$ L. aurea & 54 & 48.1 & 27 & $1 / 2 \mathrm{MS}$ & 18.5 & 14.8 \\
\hline & $\times$ L. pumila & 10 & 30.0 & 6 & $\mathrm{mMS} 2+\mathrm{CH}$ & 16.7 & 16.7 \\
\hline & $\times$ L. squamigera & 33 & 30.3 & 14 & $1 / 2 \mathrm{MS}$ & 0 & - \\
\hline & $\times$ L. albiflora & 35 & 20.0 & 3 & $1 / 2 \mathrm{MS}$ & 0 & - \\
\hline & & & & 4 & $\mathrm{mMS} 2+\mathrm{CH}$ & 0 & - \\
\hline \multirow[t]{4}{*}{ L. squamigera } & self & 59 & 61.0 & 51 & $1 / 2 \mathrm{MS}$ & 0 & - \\
\hline & $\times$ L. sanguinea & 40 & 60.0 & 41 & $1 / 2 \mathrm{MS}$ & 17.1 & 12.3 \\
\hline & $\times$ L. sprengeri & 24 & 41.7 & 20 & $\mathrm{mMS} 2+\mathrm{CH}$ & 10.0 & 5.0 \\
\hline & $\times$ L. aurea & 25 & 40.0 & 13 & $\mathrm{mMS} 2+\mathrm{CH}$ & 23.1 & 23.1 \\
\hline L. pumila & self & 32 & 75.0 & 60 & $\mathrm{mMS} 2+\mathrm{CH}$ & 58.3 & 51.7 \\
\hline L. traubii & self & 11 & 81.8 & 40 & $\mathrm{mMS} 2+\mathrm{CH}$ & 90.0 & 82.5 \\
\hline
\end{tabular}

a): The ovules were isolated 30-35 days after self- or cross-pollinations.

b): L. radiata var. pumila. 
Table 4. Results of pollination and in vitro culture in interspecific hybridization between $L$. incarnata and four Lycoris species

\begin{tabular}{|c|c|c|c|c|c|c|c|}
\hline \multicolumn{2}{|c|}{ Cross combinations } & \multirow{2}{*}{$\begin{array}{c}\text { Male } \\
\begin{array}{c}\text { Pollen } \\
\text { germination rate } \\
(\%)\end{array}\end{array}$} & \multicolumn{2}{|c|}{ Female } & \multicolumn{2}{|c|}{ No. of embryos or ovules } & \multirow{2}{*}{$\begin{array}{c}\text { No. of } \\
\text { seedlings } \\
\text { obtained }^{\text {b) }}\end{array}$} \\
\hline (우) & $\left(o^{\top}\right)$ & & $\begin{array}{c}\text { No. of florets } \\
\text { pollinated }\end{array}$ & $\begin{array}{c}\text { Capsule } \\
\text { formation }(\%)^{a)}\end{array}$ & Cultured & Germinated & \\
\hline \multirow[t]{4}{*}{ L. incarnata } & $\times$ L. sprengeri & 52.0 & 35 & 94.3 & 4 (embryo) & 4 & 4 \\
\hline & $\times$ L. pumila & 61.8 & 56 & 60.7 & 4 (embryo) & 4 & 3 \\
\hline & $\times$ L. aurea & 50.5 & 40 & 80.0 & 2 (embryo) & 1 & 1 \\
\hline & $\times$ L. sanguinea & 56.6 & 177 & 75.7 & 20 (embryo) & 20 & 16 \\
\hline L. sanguinea & $\times$ L. incarnata & 0.5 & 16 & 50.0 & 80 (ovule) & 0 & 0 \\
\hline L. incarnata & self & 2.0 & 42 & 88.1 & 90 (ovule) & 0 & 0 \\
\hline L. sanguinea & self & 46.6 & 10 & 90.0 & 27 (ovule) & 19 & 18 \\
\hline
\end{tabular}

a): (No. of capsules developed / No. of florets pollinated) $\times 100,20-30$ days after pollination.

b): After $8-12$ weeks of culture.

Table 5. Chromosome number and karyotype of interspecific hybrids and their parental plants

\begin{tabular}{|c|c|c|c|c|}
\hline \multicolumn{2}{|c|}{ Chromosome no. and karyotype of parental plants } & \multicolumn{2}{|c|}{ Hybrids } & \multirow{2}{*}{$\begin{array}{l}\text { No. of plants } \\
\text { observed }\end{array}$} \\
\hline ( 우 ) & $\left(o^{7}\right)$ & Chromosome no. & Karyotype & \\
\hline \multirow[t]{4}{*}{$\begin{array}{l}\text { L. incarnata } \\
2 \mathrm{n}=30\left(3 \mathrm{M}+5 \mathrm{~T}+20 \mathrm{~A}+1 \mathrm{M}^{\prime}+1 \mathrm{~m}\right)\end{array}$} & $\begin{array}{l}\times \text { L. sanguinea } \\
2 \mathrm{n}=22(22 \mathrm{~A})\end{array}$ & $2 n=41$ & $3 \mathrm{M}+5 \mathrm{~T}+31 \mathrm{~A}+1 \mathrm{M}^{\prime}+1 \mathrm{~m}$ & 16 \\
\hline & $\begin{array}{l}\times \text { L. sprengeri } \\
2 \mathrm{n}=22(22 \mathrm{~A})\end{array}$ & $2 n=41$ & $3 \mathrm{M}+5 \mathrm{~T}+31 \mathrm{~A}+1 \mathrm{M}^{\prime}+1 \mathrm{~m}$ & 4 \\
\hline & $\begin{array}{l}\times \text { L. pumila } \\
\quad 2 \mathrm{n}=22(22 \mathrm{~A})\end{array}$ & $2 n=41$ & $3 \mathrm{M}+5 \mathrm{~T}+31 \mathrm{~A}+1 \mathrm{M}^{\prime}+1 \mathrm{~m}$ & 5 \\
\hline & $\begin{array}{l}\times L \text {. aurea } \\
\quad 2 \mathrm{n}=14(8 \mathrm{M}+6 \mathrm{~T})\end{array}$ & $2 n=37$ & $7 \mathrm{M}+8 \mathrm{~T}+20 \mathrm{~A}+1 \mathrm{M}^{\prime}+1 \mathrm{~m}$ & 1 \\
\hline
\end{tabular}

M: Metacentrics, T: Telocentrics, A: Acrocentrics, M': Small metacentrics, m: Very small metacentrics.

$\operatorname{program}^{3,11,12}$. These studies have been performed in many plant species including some ornamental bulbs such as Tulipa ${ }^{1}$ and Iris $^{5}$. In Lycoris, there is almost no report of genetic relationships except for some cytological studies focusing on karyotype $\mathrm{e}^{20-23}$. The few genetic studies in Lycoris are probably attributed to its asexual reproduction, difficulties in producing sufficient progenies as genetic materials and long juvenile period of progenies. As mentioned in the previous section, selfed plants and interspecific hybrids were produced through ovule and embryo cultures in order to overcome these limitations. Meanwhile, in recent decades, the development of molecular marker systems (isozyme and DNAbased markers) allows genetic analyses of progenies in the seedling stage $\mathrm{e}^{1,3}$. Thus, we conducted the cytological, allozyme and genomic in situ hybridization (GISH) studies in selfed plants and interspecific hybrids for revealing specific relationships in Lycoris $^{29,30,33}$.

\section{Speciation of polyploid species estimated from cytological studies in selfed progeny}

Root tips that were excised from seedlings of selfed progenies in Table 3 and their parental plants were used for cytological study for clarifying the speciation processes of polyploid Lycoris species. For diploid species, almost all $\mathrm{S}_{1}$ progenies observed were diploid with the same karyotype as the corresponding parental species (Table 6) ${ }^{29}$. However, $\mathrm{S}_{1}$ progenies from L. sprengeri $(2 \mathrm{n}$ $=22 \mathrm{~A}$ ) included two triploids with $2 \mathrm{n}=33 \mathrm{~A}$ and one aneuploid with $2 \mathrm{n}=32(31 \mathrm{~A}+1 \mathrm{M})$, and one $\mathrm{S}_{1}$ from $L$. aurea $(2 \mathrm{n}=14,8 \mathrm{~A}+6 \mathrm{~T})$ was tetraploid with $2 \mathrm{n}=28$ $(16 \mathrm{M}+12 \mathrm{~T})$. The triploid of $L$. sprengeri was discovered in China by Zhang et al. $^{42}$, and this result demonstrated that triploid and triploid-neared aneuploid plants were induced through self-pollination of $L$. sprengeri. Since there was no report ${ }^{7,23}$ of wild tetraploid in $L$. aurea, the tetraploid plant induced in Ma \& Tarumoto $^{29}$ is the first one in L. aurea. For triploid species, L. radiata 
Table 6. Chromosome number and karyotype of selfed plants

\begin{tabular}{|c|c|c|c|}
\hline \multicolumn{2}{|c|}{ Parent } & \multicolumn{2}{|c|}{$\mathrm{S}_{1}$} \\
\hline Species & $2 n$ & $2 n$ & No. of $S_{1}$ observed \\
\hline L. sanguinea & $22 \mathrm{~A}(2 \chi)$ & $22 \mathrm{~A}$ & 84 \\
\hline L. sprengeri & $22 \mathrm{~A}(2 \chi)$ & $\begin{array}{l}22 \mathrm{~A} \\
33 \mathrm{~A} \\
32(31 \mathrm{~A}+1 \mathrm{M})\end{array}$ & $\begin{array}{r}45 \\
2 \\
1\end{array}$ \\
\hline L. aurea & $14=8 \mathrm{M}+6 \mathrm{~T}(2 \chi)$ & $\begin{array}{l}14(8 M+6 T) \\
28(16 M+12 T)\end{array}$ & $\begin{array}{r}63 \\
1\end{array}$ \\
\hline L. pumila ${ }^{\text {a) }}$ & $22 \mathrm{~A}(2 \chi)$ & $22 \mathrm{~A}$ & 21 \\
\hline L. traubii & $12=10 M+2 T(2 \chi)$ & $12(10 \mathrm{M}+2 \mathrm{~T})$ & 33 \\
\hline L. radiata $^{\text {b) }}$ & $33 \mathrm{~A}(3 \chi)$ & $\begin{array}{l}24 \mathrm{~A} \\
25 \mathrm{~A}\end{array}$ & 1 \\
\hline
\end{tabular}

a): L. radiata var. pumila.

b): L. radiata var. radiata.

Table 7. Polyploidy found in natural population of Lycoris species

\begin{tabular}{lll}
\hline \hline Taxon & $2 \mathrm{n}$ & Reference \\
\hline L. sprengeri & $22(2 \chi)$ & Inariyama $(1951 \mathrm{a})^{8}$ \\
& $33(3 \chi)$ & Zhang et al. $(1999)^{42}$ \\
L. radiata var. radiata & $33(3 \chi)$ & Inariyama $(1951 \mathrm{a})^{8}$ \\
L. radiata var. pumila & $22(2 \chi)$ & Kurita $(1988)^{21}$ \\
L. sanguinea var. sanguinea & $22(2 \chi)$ & Inariyama $(1951 \mathrm{a})^{8}$ \\
& $32(3 \chi)$ & Kurita $(1989)^{22}$ \\
L. sanguinea var. kiushiana & $22(2 \chi)$ & Kurita $(1988)^{21}$ \\
& $33(3 \chi)$ & Kurita $(1988)^{21}$ \\
& $44(4 \chi)$ & Kurita $(1988)^{21}$ \\
\hline
\end{tabular}

Process I:

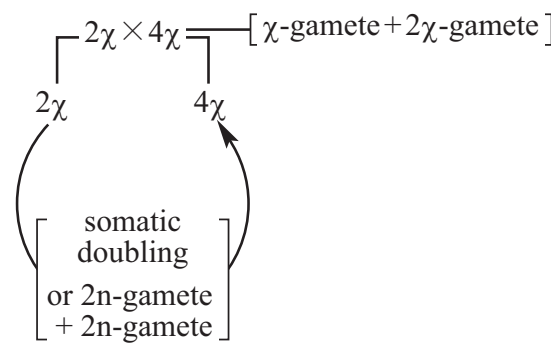

Process II: $\begin{gathered}2 \chi \times 2 \chi \\ \text { or } \\ 2 \chi \text { selfing }\end{gathered}-\left[\begin{array}{c}2 \text { n-gamete }+ \text { n-gamete } \\ \text { or one egg }+ \text { two generative nuclei }\end{array}\right]$

Fig. 2. Hypothesis for karyotype evolution in Lycoris species
$(2 \mathrm{n}=33 \mathrm{~A})$, all the $\mathrm{S}_{1}$ plants observed were aneuploid with chromosome number near to its diploid taxon, $L$. radiata var. pumila $(2 \mathrm{n}=22 \mathrm{~A})$. From the results, the evolution routes of natural polyploids shown in Table $7^{25}$ are hypothesized in Fig. $2^{25}$. For L. sprengeri and L. radi$a t a$, because there is no tetraploid found in nature ${ }^{7,23}$, those triploids would have originated by 'Process II', suggesting that unreduced gametes occasionally formed through self-pollination in 'fertile' species would be a factor inducing polyploid species in genus Lycoris.

\section{Genetic segregation of allozymes in selfed plants of diploid species}

Seven diploid species with normal meiotic division, L. aurea, L. traubii, L. sanguinea, L. sprengeri, L. radiata var. pumila (L. pumila, hereafter), L. longituba, and $L$. chinensis, were considered to be progenitors of the other species mostly on the basis of cytological studies ${ }^{7,23}$. For 
Table 8. Allozyme variation in selfed progenies of several Lycoris species

\begin{tabular}{|c|c|c|c|c|c|c|}
\hline Locus & Band pattern & L. aurea & L. traubii & L. sprengeri & L. sanguinea & L. pumila ${ }^{\text {a) }}$ \\
\hline \multirow[t]{2}{*}{ Apt-1 } & $P$ & 47 & 25 & 30 & 0 & 21 \\
\hline & A & 0 & 4 & 0 & 64 & 0 \\
\hline \multirow[t]{2}{*}{ Apt-2 } & $\mathrm{P}$ & 47 & 24 & 18 & 33 & 17 \\
\hline & A & 0 & 5 & 12 & 31 & 4 \\
\hline \multirow[t]{3}{*}{ Got-2 } & $\mathrm{F}$ & 35 & 0 & 0 & 64 & 0 \\
\hline & FS & 12 & 29 & 0 & 0 & 0 \\
\hline & $\mathrm{S}$ & 0 & 0 & 30 & 0 & 21 \\
\hline \multirow[t]{3}{*}{ Got-3 } & $\mathrm{F}$ & - & - & 0 & - & 6 \\
\hline & FS & - & - & 0 & - & 10 \\
\hline & $\mathrm{S}$ & - & - & 30 & - & 5 \\
\hline \multirow[t]{3}{*}{ Got-4 } & $\mathrm{F}$ & 0 & 0 & 0 & 2 & - \\
\hline & FS & 0 & 0 & 0 & 42 & - \\
\hline & $\mathrm{S}$ & 47 & 29 & 30 & 20 & - \\
\hline \multirow[t]{3}{*}{ Est-1 } & $\mathrm{F}$ & - & - & 12 & 13 & - \\
\hline & FS & - & - & 10 & 34 & - \\
\hline & $\mathrm{S}$ & - & - & 8 & 17 & - \\
\hline \multirow[t]{2}{*}{ Est-3 } & $\mathrm{P}$ & 0 & 0 & 0 & 24 & 15 \\
\hline & A & 47 & 29 & 30 & 40 & 6 \\
\hline No. of $\mathrm{S}_{1}$ & & 47 & 29 & 30 & 64 & 21 \\
\hline No. of parental plants & & 6 & 3 & 8 & 16 & 5 \\
\hline
\end{tabular}

P: Present, A: Absent, F: Fast migration, S: Slow migration.

- : No band. a): L. radiata var. pumila.

these diploid progenitor species, from the characteristic and karyotype analyses in interspecific hybrids, Takemura $^{36,37}$ assumed that L. aurea, L. sanguinea, $L$. sprengeri, and L. pumila would be homozygous, while Caldwell ${ }^{2}$ postulated that L. sprengeri and L. pumila would be partly heterozygous in their genetic background. It is important to know the zygotic site of the diploid species in evolutional study as well as breeding. For this aim, seedlings of selfed progenies that showed the same chromosome complements as that of their corresponding parents (Table 6), five diploid progenitor species, except L. longituba and L. chinensis, were used and the allozyme variations were investigated in them. Among 14 allozyme loci of ATP, GOT and EST, seven polymorphic loci were detected (Table 8$)^{30}$. Allozyme segregations were observed in all five species ${ }^{30}$, suggesting that each of the five diploid species, L. aurea, $L$. traubii, L. sanguinea, L. sprengeri, and L. pumila, is heterozygous. This result proved that the five diploid progenitor species originated from hybrids, and it supported that hybridization was one of the important modes of speciation $^{21,23}$.

\section{Genome differentiation in Lycoris species identified by genomic in situ hybridization}

Kurita $^{20,21}$ reported the major types of chromosomes [M (metacentrics), T (telocentrics), A (acrocentrics), and $\mathrm{m}$ (very small metacentrics)] for classifying karyotypes in the genus Lycoris. Kurita ${ }^{21}$ also suggested that genomes composed of $\mathrm{M}$ and $\mathrm{T}$ type chromosomes like L. longituba $(6 \mathrm{M}+10 \mathrm{~T})$ were ancestral and that genomes composed entirely of A type chromosomes like $L$. sprengeri (22A) were derivatives. However, detailed genome analysis in Lycoris had not been performed. Thus, the chromosomes of six Lycoris species and three interspecific hybrids were investigated using genomic in situ hybridization (GISH) to clarify the chromosome constitution in this genus. Total DNA from $L$. aurea $(2 \mathrm{n}=$ $13,9 \mathrm{M}+4 \mathrm{~T})$ and L. sprengeri $(2 \mathrm{n}=22,22 \mathrm{~A})$ was used as probe and blocking DNA, respectively. All the chromosomes of L. aurea $(9 \mathrm{M}+4 \mathrm{~T})$ and L. longituba $(6 \mathrm{M}+$ $10 \mathrm{~T})$ were hybridized with probe DNA and were visualized as yellow labeled chromosomes, while those of $L$. sprengeri (22A), L. pumila (22A) and L. sanguinea (22A) remained unlabeled and appeared as red chromosomes 
Table 9. Origins, cytological characteristics, and results of GISH analyses of 6 Lycoris species and 3 interspecific hybrids in which total DNA from $L$. aurea and $L$. sprengeri were used as probe and blocking DNA, respectively

\begin{tabular}{|c|c|c|c|c|c|c|c|}
\hline \multirow{2}{*}{\multicolumn{2}{|c|}{$\begin{array}{l}\text { Species (origin) } \\
\text { and interspecific hybrids }\end{array}$}} & \multirow{3}{*}{$\begin{array}{c}\begin{array}{c}\text { Chromosome } \\
\text { no. }\end{array} \\
2 n=13\end{array}$} & \multirow{3}{*}{$\begin{array}{l}\text { Karyotype } \\
9 M+4 T\end{array}$} & \multicolumn{4}{|c|}{ No. of chromosomes detected by GISH } \\
\hline & & & & \multicolumn{2}{|c|}{ L. aurea type } & \multicolumn{2}{|c|}{ L. sprengeri type } \\
\hline L. aurea & (China) & & & 13 & $(9 \mathrm{M}, 4 \mathrm{~T})$ & 0 & \\
\hline L. longituba & (China) & $2 n=16$ & $6 \mathrm{M}+10 \mathrm{~T}$ & 16 & $(6 \mathrm{M}, 10 \mathrm{~T})$ & 0 & \\
\hline L. sprengeri & (China) & $2 n=22$ & $22 \mathrm{~A}$ & 0 & & 22 & $(22 \mathrm{~A})$ \\
\hline L. pumila ${ }^{\text {a) }}$ & (China) & $2 n=22$ & $22 \mathrm{~A}$ & 0 & & 22 & $(22 \mathrm{~A})$ \\
\hline L. sanguinea & (Japan) & $2 n=22$ & $22 \mathrm{~A}$ & 0 & & 22 & $(22 \mathrm{~A})$ \\
\hline L. incarnata & (China) & $2 n=30$ & $3 \mathrm{M}+5 \mathrm{~T}+20 \mathrm{~A}+1 \mathrm{M}^{\prime}+1 \mathrm{~m}$ & 8 & $(3 \mathrm{M}, 5 \mathrm{~T})$ & 22 & $\left(20 \mathrm{~A}, 1 \mathrm{M}^{\prime}, 1 \mathrm{~m}\right)$ \\
\hline \multicolumn{2}{|c|}{ L. incarnata $\times$ L. sprengeri } & $2 n=41$ & $3 \mathrm{M}+5 \mathrm{~T}+31 \mathrm{~A}+1 \mathrm{M}^{\prime}+1 \mathrm{~m}$ & 8 & $(3 \mathrm{M}, 5 \mathrm{~T})$ & 33 & $\left(31 \mathrm{~A}, 1 \mathrm{M}^{\prime}, 1 \mathrm{~m}\right)$ \\
\hline \multicolumn{2}{|c|}{ L. incarnata $\times$ L. pumila } & $2 n=41$ & $3 \mathrm{M}+5 \mathrm{~T}+31 \mathrm{~A}+1 \mathrm{M}^{\prime}+1 \mathrm{~m}$ & 8 & $(3 \mathrm{M}, 5 \mathrm{~T})$ & 33 & $\left(31 \mathrm{~A}, 1 \mathrm{M}^{\prime}, 1 \mathrm{~m}\right)$ \\
\hline \multicolumn{2}{|c|}{ L. incarnata $\times$ L. sanguinea } & $2 n=41$ & $3 \mathrm{M}+5 \mathrm{~T}+31 \mathrm{~A}+1 \mathrm{M}^{\prime}+1 \mathrm{~m}$ & 8 & $(3 \mathrm{M}, 5 \mathrm{~T})$ & 33 & $\left(31 \mathrm{~A}, 1 \mathrm{M}^{\prime}, 1 \mathrm{~m}\right)$ \\
\hline
\end{tabular}

M: Metacentrics, T: Telocentrics, A: Acrocentrics, M': Small metacentrics, m: Very small metacentrics.

a): L. radiata var. pumila.
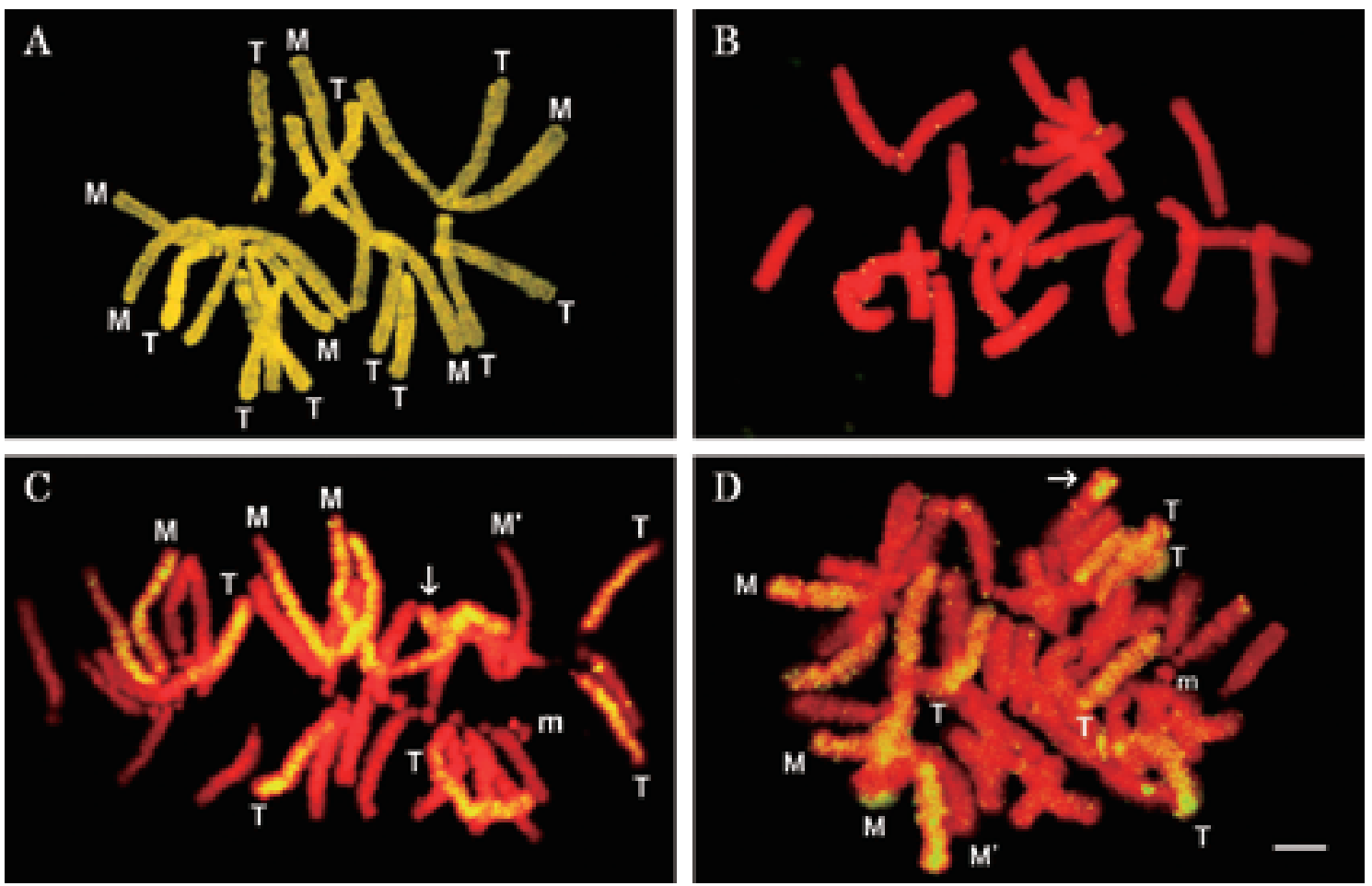

Fig. 3. Genomic in situ hybridization on the chromosomes of L. longituba (A), L. pumila (B), L. incarnata (C), and $L$. incarnata $\times$ L. pumila (D)

Total DNA of $L$. aurea and $L$. sprengeri were used as probe and blocking DNA, respectively.

Hybridization signals are visualized in yellow. Each chromosome type except A is displayed in the figure.

Arrows indicate the translocation on A type chromosomes. Scale bar $=10 \mu \mathrm{m}$. 
(Table 9 \& Fig. 3) ${ }^{33}$. Eight labeled $(3 \mathrm{M}+5 \mathrm{~T})$ and 22 unlabeled chromosomes $\left(20 \mathrm{~A}+1 \mathrm{M}^{\prime}+1 \mathrm{~m}\right)$ in $L$. incarnata, and eight labeled $(3 \mathrm{M}+5 \mathrm{~T})$ and 33 unlabeled chromosomes $\left(31 \mathrm{~A}+1 \mathrm{M}^{\prime}+1 \mathrm{~m}\right)$ in three interspecific hybrids between $L$. incarnata and 3 diploid species were detected in GISH (Table 9 \& Fig. 3) ${ }^{33}$. The distinction between $\mathrm{M}+\mathrm{T}$ and $\mathrm{A}$ type chromosomes at the DNA sequence level by GISH demonstrated that genome differentiation had occurred in the genus Lycoris. L. incarnata is confirmed to be an allotriploid species derived from the fusion of normal reduced gametes of a species with $6 \mathrm{M}+10 \mathrm{~T}$ and unreduced gametes of a species with $22 \mathrm{~A}$ or $20 \mathrm{~A}+1 \mathrm{M}^{\prime}+1 \mathrm{~m}$, which was assumed by Kurita $^{21}$. Intergenomic translocation was considered to be one of the factors in speciation in Lycoris $^{21}$ as well as in Avena ${ }^{6}$, Triticum ${ }^{41}$ and others ${ }^{13,14}$. Translocation from $\mathrm{M}$ or $\mathrm{T}$ type chromosomes to A type chromosomes was observed in L. incarnata, suggesting that intergenomic translocation affected the speciation of $L$. incarnata.

\section{Conclusion}

This report revealed some progress in overcoming problems which impede genetic and breeding studies in genus Lycoris. An improved ovule culture method was developed to rescue abortive embryos, and a large number of selfed plants and true interspecific hybrids in several Lycoris species was produced by using it. Hybrids of $3 \chi$ (female) $\times 2 \chi$ (male) were all aneuploids, suggesting that interspecific hybridization of $3 \chi \times 2 \chi$ would become an effective breeding method for increasing the character variation in Lycoris. Moreover, interspecific hybrids between $L$. incarnata (sterile) and four fertile species were successfully obtained for the first time and would be promising breeding materials. However, in order to produce hybrid plants more efficiently, the mechanism of embryo abortion and methods of embryo rescue need to be studied further.

In cytological studies of the $\mathrm{S}_{1}$ obtained through ovule culture, polyploidization and aneuploid reduction caused by self-pollination were shown to be among the major factors affecting karyotype evolution in some Lycoris species. The allozyme segregation in $\mathrm{S}_{1}$ proved the heterozygous nature of the fertile Lycoris species, suggesting that varietal and specific differentiation would be easily caused by self- and cross-pollination in Lycoris. Not only the genomic differentiation but also intergenomic translocation from $\mathrm{M}$ or $\mathrm{T}$ type chromosomes to A type chromosomes were revealed by genomic in situ hybridization. These results will become useful information for making progress in genetic and breeding studies in genus Lycoris.

\section{References}

1. Booy, G. \& van Raamsdonk, L. W. D. (1998) Variation in the enzyme esterase within and between Tulipa species; usefulness for the analysis of genetic relationships at different taxonomical levels. Biochem. Sys. Ecol., 26, 199224.

2. Caldwell, S. (1964) Lycoris report 1963. Plant Life, 20, 55-61.

3. Charmet, G. \& Balfourier, F. (1994) Isozyme variation and species relationships in the genus Lolium L. (ryegrasses, Graminaceae). Theor. Appl. Genet., 87, 641649.

4. Coertze, A. F. \& Louw, E. (1990) The breeding of interspecies and intergenera hybrids in the Amaryllidaceae. Acta Hort., 266, 349-352.

5. Hannan, G. L. \& Orick, M. W. (2000) Isozyme diversity in Iris cristata and the threatened glacial endemic $I$. lacustris (Iridaceae). Am. J. Bot., 87, 293-301.

6. Hayasaki, M., Morikawa, T. \& Tarumoto, I. (2000) Intergenomic translocations of polyploid oats (genus Avena) revealed by genomic in situ hybridization. Genes Genet. Syst., 75, 167-171.

7. Hsu, P. S. et al. (1994) Synopsis of the genus Lycoris (Amaryllidaceae). Sida, 16, 301-331.

8. Inariyama, S. (1951a) Cytological studies in the genus Lycoris (I). Sci. Rep. Tokyo Bunrika Daigaku, Sect. B., 6, 74-100.

9. Inariyama, S. (1951b) Cytological studies in the genus Lycoris (II). Sci. Rep. Tokyo Bunrika Daigaku, Sect. B., 7, 103-156.

10. Isobe, Y. \& Yazawa, S. (1993) Producing of interspecific hybrids of Lycoris in vitro culture. J. Jpn. Soc. Hort. Sci., 62 (Suppl. 1), 340-341 [In Japanese].

11. Janaki-Ammal, E. K. (1951) The chromosome history of cultivated Nerines. J. Roy. Hort. Soc., 76, 365-371.

12. Jensen, N. F. (1988) Plant breeding methodology. Wiley, New York, 415-657.

13. Jones, K. (1978) Aspects of chromosome evolution in higher plants. Adv. Bot. Res., 6, 120-194.

14. Jones, K. (1998) Robertsonian fusion and centric fission in karyotype evolution of higher plants. Bot. Rev., 64, 273-289.

15. Katsukawa, K., Mori, G. \& Imanishi, H. (2000) Effect of applying naphthaleneacetic acid (NAA) onto stigma on fruit set and seed formation in interspecific hybrids between Lycoris species. J. Jpn. Soc. Hort. Sci., 69, 224226 [In Japanese with English summary].

16. Kihara, H. \& Koyama, M. (1954) Offspring obtained by self-pollination of Lycoris radiata Herb., a triploid species. Jpn. J. Genet., 29, 160-161.

17. Koyama, M. (1953) Cytological studies in the genus Lycoris (I). Cytological studies on the hybrid of Lycoris radiata Herb. $\times$ L. sanguinea Maxim. Ann. Rep. Doshisha Women's Coll., 4, 128-141.

18. Koyama, M. (1955) Cytological studies in the genus Lycoris (II). The hybrid of Lycoris radiata Herb. $\times L$. sanguinea Maxim. Ann. Rep. Doshisha Women's Coll., 6, 285-291.

19. Koyama, M. (1959) Offspring of Lycoris radiata obtained by artificial self-pollination. Ann. Rep. Dosh- 
isha Women's Coll., 10, 388-394.

20. Kurita, S. (1986) Variation and evolution in the karyotype of Lycoris, Amaryllidaceae I. General karyomorphological characteristics of the genus. Cytologia, 51, 803-815.

21. Kurita, S. (1988) Variation and evolution in the karyotype of Lycoris, Amaryllidaceae VII. Modes of karyotype alteration within species and probable trend of karyotype evolution in the genus. Cytologia, 53, 323-335.

22. Kurita, S. (1989) Variation and evolution in the karyotype of Lycoris (Amaryllidaceae) V. Chromosome variation in L. sanguinea Maxim. Plant Species Biol., 4, 47-60.

23. Kurita, S. \& Hsu, P. S. (1998) Cytological patterns in the Sino-Japanese flora hybrid complexes in Lycoris, Amaryllidaceae. Univ. Mus., Univ. Tokyo, Bull., 37, 171-180.

24. Le Nard, M. \& De Hertogh, A. A. (1993) Plant breeding and genetics. In The physiology of flower bulbs-A comprehensive treatise on the physiology and utilization of ornamental flowering bulbous and tuberous plants, ed. De Hertogh, A. A., Elsevier, Amsterdam, London, New York, Tokyo, 161-169.

25. Ma, B. (2001) Development of plant tissue culture techniques and its application to genetic and breeding studies in Lycoris and related genera. Ph. D. Thesis, Osaka Prefecture Univ., Japan.

26. Ma, B., Tarumoto, I. \& Morikawa, T. (2000) Cytological studies on selfed plants and interspecific crosses produced in four species of genus Lycoris (Amaryllidaceae). Sci. Rep. Coll. Agric. Osaka Pref. Univ., 52, 1318.

27. Ma, B., Tarumoto, I. \& Liu, Q. C. (2001) An improved method of ovule culture for producing interspecific hybrids in the genus Lycoris (Amaryllidaceae). J. Jpn. Soc. Hort. Sci., 70, 460-462.

28. Ma, B. et al. (2001) Production of interspecific hybrids between Lycoris incarnata and four other Lycoris species through embryo culture. J. Jpn. Soc. Hort. Sci., 70, 697703 .

29. Ma, B. \& Tarumoto, I. (2002) Speciation of polyploid Lycoris species estimated from cytological studies in selfed progeny. J. Jpn. Soc. Hort. Sci., 71, 780-782.

30. Ma, B., Ogawa, T. \& Tarumoto, I. (2004) Genetic segregation of allozymes in selfed progenies of diploid Lycoris species (Amaryllidaceae). Sci. Rep. Grad. Sch. Agric. \& Biol. Sci. Osaka Pref. Univ., 56, 17-22.
31. Monnier, M. (1976) Culture in vitro de l'embryon immature de Capsella bursa-pastoris Moench (L.). Rev. Cytol. Biol. Vég., 39, 1-120.

32. Nishiyama, I. (1928) Reduction division in Lycoris. Bot. Mag. Tokyo, 42, 509-513.

33. Ogawa, T. et al. (2005) Genome differentiation in Lycoris species (Amaryllidaceae) identified by genomic in situ hybridization. Breed. Sci., 55, 265-269.

34. Shii, C. T. et al. (1997) Nucleotype remodeling in interspecific hybridization of Lycoris aurea Herb. and Lycoris radiata Herb. Acta Hort., 430, 521-527.

35. Takemura, E. (1961) Morphological and cytological studies on artificial hybrids in the genus Lycoris I. On $\mathrm{F}_{1}$ hybrid between $L$. sprengeri Comes and L. straminea Lindl. Bot. Mag. Tokyo, 74, 524-531 [In Japanese with English summary].

36. Takemura, E. (1962a) Morphological and cytological studies on artificial hybrids in the genus Lycoris II. Artificial hybrids among the different species having only rodshaped chromosomes. Bot. Mag. Tokyo, 75, 72-79 [In Japanese with English summary].

37. Takemura, E. (1962b) Morphological and cytological studies on artificial hybrids in the genus Lycoris III. An artificial hybrid having four V-shaped chromosomes. Bot. Mag. Tokyo, 75, 324-330 [In Japanese with English summary].

38. Tokugawa, Y. \& Emoto, Y. (1930) Über die samenbildung in Lycoris-Arten. Bot. Mag. Tokyo, 44, 236-244.

39. Van Tuyl, J. M. (1997) Interspecific hybridization of flower bulbs: a review. Acta Hort., 430, 465-476.

40. Wylie, A. P. (1952) The history of the garden Narcisii. Heredity, 6, 137-156.

41. Zhang, X., Dong, Y. \& Wang, R. R. -C. (1996) Characterization of genomes and chromosomes in partial amphiploids of the hybrid Triticum aestivum $\times$ Thinopyrum ponticum by in situ hybridization, isozyme analysis, and RAPD. Genome, 39, 1062-1071.

42. Zhang, D. C. et al. (1999) The discovery of triploid Lycoris sprengeri Comes ex Baker from Anhui, China. Acta Phytotaxonom. Sin., 37, 35-39.

43. Ziebur, N. K. et al. (1950) The effect of casein hydrolysate on the growth in vitro of immature Hordeum embryos. Am. J. Bot., 37, 144-148. 